\title{
3-(IMIDAZOL-1-YL)PROPANE-1,2-DIOL AND 3-(1,2,4- TRIAZOL-1-YL)PROPANE-1,2-DIOL: SYNTHESIS AND THEIR TRANSFORMATION TO BIOACTIVE CYCLIC KETALS
}

\author{
V.S. Talismanov ${ }^{1, \bigotimes}$, S.V. Popkov ${ }^{2}$, O.G. Karmanova ${ }^{1}$, S.S. Zykova ${ }^{3}$, \\ M.V. Shustov ${ }^{3}$, L.A. Zhuravleva ${ }^{4}$ and N.G. Tokareva ${ }^{5}$ \\ ${ }^{1}$ Depatment of Chemistry, Moscow Institute of Physics and Technology, Dolgoprudny, Moscow \\ Region, Russian Federation \\ ${ }^{2}$ Department of Chemistry and Technology of Organic Synthesis, D. Mendeleev University of \\ Chemical Technology of Russia, Moscow, Russian Federation \\ ${ }^{3}$ Department of Pharmacology, Perm State Pharmaceutical Academy, Perm, Russian Federation \\ ${ }^{4}$ Depatment of Chemistry, Surgut State University, Surgut, Russian Federation \\ ${ }^{5}$ Depatment of nervous diseases and psychiatry, National research Ogarev Mordovia State \\ University, Medical Institute, Saransk, Russian Federation \\ ${ }^{\bowtie}$ Corresponding Author: talismanov@phystech.edu
}

\begin{abstract}
3-(Imidazol-1-yl)propane-1,2-diol and 3-(1,2,4-triazol-1-yl)propane-1,2-diol were obtained by three alternative synthetic pathways such as hydrolysis of 1-[(1,3-dioxolan-4-yl)methyl]-azoles, Wagner reaction of N-allylazoles and reaction of glycidol with imidazole or 1,2,4-triazole. The 4-(azol-1-ylmethyl)-1,3-dioxolanes can be synthesized by reaction of 3-(imidazol-1-yl)propane-1,2-diol or 3-(1,2,4-triazol-1-yl)propane-1,2-diol with ketones to substituted 4azolylmethyl-1,3-dioxolanes
\end{abstract}

Keywords: N-allylazoles, Glycidol, Diols, 1,3-dioxolane, Imidazole, 1,2,4-triazole, Wagner Reaction.

RASĀYAN J. Chem., Vol. 14, No.3, 2021

\section{INTRODUCTION}

Aminopropanediols are known to have diverse biological activities: antimicrobial, antifungal; the effect of aminopropanediols on the enzyme activity of human blood enzymes: lactate dehydrogenase, $\alpha$-amylase, $\gamma$ glutamyl transferase, alkaline phosphatase, alanine aminotransferase, aspartate aminotransferase have been described ${ }^{1}$. Highly effective antioxidants and antihypoxants ${ }^{2}$, fungicides $\mathrm{s}^{3,4,5}$ and antimycotics ${ }^{6}$, antibacterial drugs $^{7,8}$, cytostatics ${ }^{9}$, were found among the derivatives of 1,2,4-triazole ${ }^{10,11,12}$ and imidazole ${ }^{13,14}$ with 1,3 dioxolane fragment.

Combining both 1,2,4-triazole or imidazole fragments and diols in a single molecule can lead to the production of new substances with a variety of biological activities.

\section{Material and Methods}

\section{EXPERIMENTAL}

Industrial reagents (Sigma Aldrich) were used without further purification. The reactions were carried out in the air atmosphere. Melting points of the compounds were determined in open capillaries and are uncorrected. ${ }^{1} \mathrm{H}$ NMR spectra were recorded on a Bruker AM-200 spectrometer (200.13 MHz) with Me $4 \mathrm{Si}$ internal reference standard. IR spectra were recorded from a thin layer on a Specord M-80 device. The reaction and the purity of the compounds were tested by TLC (Sorbfil A-UV). The data of the element analysis were close or coincided with the calculated data. 
RASĀYAN J. Chem.

Vol. 14 | No. 3 |1711-1716| July - September | 2021

\section{General Procedure}

\section{2,2-Dimethyl-4-chloromethyl-1,3-dioxolane (1)}

$79.55 \mathrm{~g}(860 \mathrm{mmol})$ of epichlorohydrin were added with stirring to a mixture of $50 \mathrm{~g}(860 \mathrm{mmol})$ of acetone and $4.83 \mathrm{~g}(2.1 \mathrm{ml}, 34 \mathrm{mmol})$ of boron trifluoride etherate at a temperature not exceeding $40{ }^{\circ} \mathrm{C}$. The reaction mixture was stirred at $20^{\circ} \mathrm{C}$ for 120 min and washed with $0.1 \mathrm{~L}$ of $3 \% \mathrm{NaOH}$ solution, $0.1 \mathrm{~L}$ of water, dried with $\mathrm{MgSO}_{4}$, and fractionated at atmospheric pressure. Fractions with a boiling point below $155{ }^{\circ} \mathrm{C}$ were discarded, fractions with a boiling point of $155-162{ }^{\circ} \mathrm{C}$ were collected. $74.9 \mathrm{~g}(58 \%)$ of 2,2-dimethyl-4chloromethyl-1,3-dioxolane were obtained as a colorless yellowish oily liquid, $\mathrm{n}_{\mathrm{D}}{ }^{20} 1.4353$. NMR ${ }^{1} \mathrm{H}$ $\left(\mathrm{CDCl}_{3}, \delta, \mathrm{ppm}, \mathrm{J} / \mathrm{Hz}\right): 1.38\left(\mathrm{~s}, 3 \mathrm{H}, \mathrm{CH}_{3}\right) ; 1.46\left(\mathrm{~s}, 3 \mathrm{H}, \mathrm{CH}_{3}\right) ; 3.45\left(\mathrm{dd}, 1 \mathrm{H}, \mathrm{CH}_{2},{ }^{3} \mathrm{~J}=7.1,{ }^{2} \mathrm{~J}=10.5\right) ; 3.58(\mathrm{dd}$, $\left.1 \mathrm{H}, \mathrm{CH}_{2},{ }^{3} \mathrm{~J}=4.8,{ }^{2} \mathrm{~J}=10.5\right) ; 3.87\left(\mathrm{dd}, 1 \mathrm{H}, \mathrm{CH}_{2} \mathrm{O},{ }^{3} \mathrm{~J}=4.7,{ }^{2} \mathrm{~J}=8.8\right) ; 4.11\left(\mathrm{dd}, 1 \mathrm{H}, \mathrm{CH}_{2},{ }^{3} \mathrm{~J}=6.1,{ }^{2} \mathrm{~J}=8.8\right) ; 4.31(\mathrm{q}$, $1 \mathrm{H}, \mathrm{CHO},{ }^{3} \mathrm{~J}=5.5$ ). IR (thin-film, $v / \mathrm{sm}^{-1}$ ): 1245, 1210, 1181, 1137, 1051, 741 .

\section{2,2-Dimethyl-4-(1,2,4-triazol-1-ylmethyl)-1,3-dioxolane (2)}

A mixture of $35 \mathrm{~g}$ of (230 mmol) 2,2-dimethyl-4-chloromethyl-1,3-dioxolane, $20.97 \mathrm{~g}(230 \mathrm{mmol})$ of 1,2,4sodium triazolate and $0.15 \mathrm{~L}$ of DMF was boiled under intensive stirring for $16,5 \mathrm{~h}$. The reaction mass was cooled, filtered, the filtrate was evaporated, and the residue was distilled in the oil pump vacuum. Fractions with a boiling point of $105-115{ }^{\circ} \mathrm{C} / 0.05 \mathrm{~mm} \mathrm{Hg}$ were collected; $19 \mathrm{~g}(78 \%)$ of yellowish oil were obtained, $\mathrm{n}_{\mathrm{D}}{ }^{20} 1.4724$. NMR ${ }^{1} \mathrm{H}\left(\mathrm{CDCl}_{3}, \delta, \mathrm{ppm}, \mathrm{J} / \mathrm{Hz}\right): 1.31\left(\mathrm{~s}, 3 \mathrm{H}, \mathrm{CH}_{3}\right) ; 1.32\left(\mathrm{~s}, 3 \mathrm{H}, \mathrm{CH}_{3}\right) ; 3.77\left(\mathrm{dd}, 1 \mathrm{H}, \mathrm{CH}_{2}\right.$, $\left.{ }^{3} \mathrm{~J}=5.8,{ }^{2} \mathrm{~J}=8.6\right) ; 4.09\left(\mathrm{dd}, 1 \mathrm{H}, \mathrm{CH}_{2},{ }^{3} \mathrm{~J}=6.1,{ }^{2} \mathrm{~J}=8.6\right) ; 4.29\left(\mathrm{dd}, 2 \mathrm{H}, \mathrm{CH}_{2},{ }^{3} \mathrm{~J}=4.4,{ }^{2} \mathrm{~J}=8.2\right) ; 4.42$ (q, $1 \mathrm{H}, \mathrm{CH}$, $\left.{ }^{3} \mathrm{~J}=5.8\right) ; 7.93$ (s, 1H, tr.); 8.15 (s, 1H, tr.). IR (thin-film, v/sm ${ }^{-1}$ ): 1487, 1259, 1047, 1214, 1177, 1127, 1063.

2,2-Dimethyl-4-(imidazol-1-ylmethyl)-1,3-dioxolane (3) was obtained similar to (2). Yield 68\%, yellowish oil, $\mathrm{n}_{\mathrm{D}}{ }^{20} 1.4925 . \mathrm{NMR}{ }^{1} \mathrm{H}\left(\mathrm{CDCl}_{3}, \delta, \mathrm{ppm}, \mathrm{J} / \mathrm{Hz}\right): 1.33\left(\mathrm{~s}, 3 \mathrm{H}, \mathrm{CH}_{3}\right) ; 1.37\left(\mathrm{~s}, 3 \mathrm{H}, \mathrm{CH}_{3}\right) ; 3.62(\mathrm{dd}$, $\left.1 \mathrm{H}, \mathrm{CH}_{2},{ }^{3} \mathrm{~J}=6.7,{ }^{2} \mathrm{~J}=8.6\right) ; 3.94-4.13\left(\mathrm{~m}, 3 \mathrm{H}, \mathrm{CH}_{2}\right) ; 4.32\left(\mathrm{q}, 1 \mathrm{H}, \mathrm{CH},{ }^{3} \mathrm{~J}=5.8\right) ; 6.96(\mathrm{~s}, 1 \mathrm{H}, \mathrm{im}$ ) $; 7.04(\mathrm{~s}, 1 \mathrm{H}$, im.); 7.50 (s, 1H, im.). IR (thin-film, v/sm ${ }^{-1}$ ): 1486, 1258, 1046, 1213, 1177, 1127, 1063.

\section{N-Allyl-1,2,4-triazole (4)}

A solution of $15 \mathrm{~g}(160 \mathrm{mmol})$ of sodium triazolate in $0.05 \mathrm{~L}$ of absolute ethanol was cooled to $0{ }^{\circ} \mathrm{C}$ and $28.8 \mathrm{~g}(20.6 \mathrm{ml}, 240 \mathrm{mmol})$ of 3-bromoprop-1-ene were added at $5{ }^{\circ} \mathrm{C}$. The reaction mass was stirred for $12,5 \mathrm{~h}$, boiled for 3 hours, cooled, filtered, the filtrate was boiled down, and the residue was fractionated in the oil pump vacuum. The fraction with a boiling point of $55-64{ }^{\circ} \mathrm{C} / 0.1 \mathrm{~mm} \mathrm{Hg}$ was collected. $9.2 \mathrm{~g}(53 \%)$ of product in the form of a yellowish liquid were obtained. $\mathrm{n}_{\mathrm{D}}{ }^{20} 1.4818$. NMR ${ }^{1} \mathrm{H}\left(\mathrm{CDCl}_{3}, \delta, \mathrm{ppm}, \mathrm{J} / \mathrm{Hz}\right)$ : $4.78\left(\mathrm{~d}, 2 \mathrm{H}, \mathrm{CH}_{2},{ }^{3} \mathrm{~J}=6,1\right) ; 5.22\left(\mathrm{~d}, 1 \mathrm{H},-\mathrm{CH}_{2},{ }^{3} \mathrm{~J}=16.8\right) ; 5.33\left(\mathrm{~d}, 1 \mathrm{H},-\mathrm{CH}_{2},{ }^{3} \mathrm{~J}=10.6\right) ; 5.90-6.10(\mathrm{~m}, 1 \mathrm{H},-\mathrm{CH}$, ${ }^{3} \mathrm{~J}=10.6,{ }^{3} \mathrm{~J}=17.2,{ }^{3} \mathrm{~J}=6.1$ ); 7.95 (s, $1 \mathrm{H}$, tr.); 8.08 (s, 1H, tr.). IR (thin-film, $\left.v / \mathrm{sm}^{-1}\right): 1623,1487$.

\section{N-Allyl-imidazole (5)}

$17.76 \mathrm{~g}$ (148 $\mathrm{mmol})$ of 3-bromoprop-1-ene were added to the mixture of $50 \mathrm{~g}(740 \mathrm{mmol})$ of imidazole and $12.43 \mathrm{~g}(148 \mathrm{mmol})$ of sodium bicarbonate in $0,1 \mathrm{~L}$ of methanol at $15-20^{\circ} \mathrm{C}$ and stirred at $20^{\circ} \mathrm{C}$ for $120 \mathrm{~h}$. The reaction mass was filtered dry, the filtrate was boiled down, the residue was distilled in the oil pump vacuum, and the fraction with a boiling point of $70-90{ }^{\circ} \mathrm{C} / 0.08 \mathrm{~mm} \mathrm{Hg}$ was collected. $14.9 \mathrm{~g}(93 \%)$ of the product was obtained in the form of a colorless liquid, $\mathrm{n}_{\mathrm{D}}{ }^{20} 1.5054$. $\mathrm{NMR}{ }^{1} \mathrm{H}\left(\mathrm{CDCl}_{3}, \delta, \mathrm{ppm}, \mathrm{J} / \mathrm{Hz}\right): 4.51$ $\left(\mathrm{d}, 2 \mathrm{H}, \mathrm{CH}_{2},{ }^{3} \mathrm{~J}=5.8\right) ; 5.15\left(\mathrm{~d}, 1 \mathrm{H},-\mathrm{CH}_{2},{ }^{3} \mathrm{~J}=18.3\right) ; 5.24\left(\mathrm{~d}, 1 \mathrm{H},-\mathrm{CH}_{2},{ }^{3} \mathrm{~J}=11.7\right) ; 5.86-5.99$ (m, $\left.1 \mathrm{H}, \mathrm{CH}\right)$; 6.87 (s, 1H); 7.04 (s, 1H, im.); 7.44 (s, 1H, im.). IR (thin-film, v/sm-1): 1625, 1485.

\section{3-(Azol-1-yl)propane-1,2-diols (6, 7) Method-I}

A mixture of $5.05 \mathrm{~g}$ (27.6 mmol) of 2,2-dimethyl-4-(1,2,4-triazol-1-ylmethyl)-1,3-dioxolane, $10 \mathrm{ml}$ of methanol and $1.01 \mathrm{~g}(0.85 \mathrm{ml}, 27.6 \mathrm{mmol})$ of concentrated hydrochloric acid boiled for $120 \mathrm{~min}$. The reaction mass was cooled, neutralized with a $4 \% \mathrm{NaOH}$ solution to $\mathrm{pH} \sim 7$, and methanol and water were boiled down. The resulting technical product was dissolved by heating in acetonitrile, filtered, the filtrate was boiled down and the acetonitrile residues were removed in a high vacuum. $3.94 \mathrm{~g}$ (99 \%) of 3-(1,2,4- 
triazol-1-yl)propane-1,2-diol were obtained. Similarly, 3-(imidazol-1-yl)propane-1,2-diol were obtained, with a yield of $86 \%$.

\section{Method-II}

A solution of $4.97 \mathrm{~g}(46 \mathrm{mmol})$ of $\mathrm{N}$-allylimidazole in $0.07 \mathrm{~L}$ of water was cooled to $0{ }^{\circ} \mathrm{C}$ and a solution of $7.3 \mathrm{~g}(46 \mathrm{mmol})$ of $\mathrm{KMnO}_{4}$ in $0.150 \mathrm{~L}$ of water, cooled to $5{ }^{\circ} \mathrm{C}$, was added. The resulting mass was stirred for $3,5 \mathrm{~h}$, and heated for $1.5 \mathrm{~h}$ in a boiling water bath. The reaction mass was filtered using a Buchner funnel, the filtrate was boiled down, and the residue was recrystallized from acetonitrile. $4.21 \mathrm{~g}(65 \%)$ of 3-(1H-imidazol-1-yl)propane1,2-diols were obtained. 3-(1,2,4-triazol-1-yl)propane-1,2-diol with a yield of $73 \%$ were obtained in the same way.

\section{Method-III}

$12.0 \mathrm{~g}(160 \mathrm{mmol})$ of glycidol were slowly added to a solution of $13.8 \mathrm{~g}(200 \mathrm{mmol})$ of imidazole in 0.05 $\mathrm{L}$ of acetonitrile, and heated at $50{ }^{\circ} \mathrm{C}$ for 3 hours. The lower layer was separated, boiled down, and purified by flash chromatography (eluent was a 3:1 mixture of ethyl acetate and methanol); $14.8 \mathrm{~g}(65 \%)$ of the product was obtained in the form of a yellow oily liquid that crystallized over time.

3-(1,2,4-Triazol-1-yl)propane-1,2-diol (6), white crystals., m.p. $64-65{ }^{\circ} \mathrm{C}$. NMR ${ }^{1} \mathrm{H}(\mathrm{DMSO}-\mathrm{d} 6, \delta$, ppm, $\mathrm{J} / \mathrm{Hz}): 3.32\left(\mathrm{~d}, 2 \mathrm{H}, \mathrm{CH}_{2},{ }^{3} \mathrm{~J}=6.3\right) ; 3.78\left(\mathrm{q}, 1 \mathrm{H}, \mathrm{CH},{ }^{3} \mathrm{~J}=5.8\right) ; 4.05\left(\mathrm{dd}, 1 \mathrm{H}, \mathrm{CH}_{2},{ }^{3} \mathrm{~J}=8.1,{ }^{3} \mathrm{~J}=13.8\right) ; 4.26(\mathrm{dd}$, $1 \mathrm{H}, \mathrm{CH}_{2},{ }^{3} \mathrm{~J}=4.1,{ }^{2} \mathrm{~J}=3.8$ ); 5.00 (br.s, $\left.2 \mathrm{H}, \mathrm{OH}\right) ; 7.93$ (s, $1 \mathrm{H}$, tr.); 8.39 (s, $1 \mathrm{H}$, tr.). IR (thin-film, v/sm ${ }^{-1}$ ): $3147-$ $3479,1493,1259,667,753$.

3-(Imidazol-1-yl)propane-1,2-diol (7), white crystals, m.p. $60-61{ }^{\circ} \mathrm{C}$, b.p. $185-215{ }^{\circ} \mathrm{C} / 0.1 \mathrm{~mm} \mathrm{Hg},{ }^{1} \mathrm{H}$ (DMSO-d6, $\delta$, ppm, J/Hz): $3.21\left(\mathrm{dd}, 1 \mathrm{H}, \mathrm{CH}_{2},{ }^{3} \mathrm{~J}=6.5,{ }^{2} \mathrm{~J}=10.9\right) ; 3.34\left(\mathrm{dd}, 1 \mathrm{H}, \mathrm{CH}_{2},{ }^{3} \mathrm{~J}=5.8,{ }^{2} \mathrm{~J}=10.9\right) ; 3.67$ (q, $1 \mathrm{H}, \mathrm{CH},{ }^{3} \mathrm{~J}=4.9$ ); 3.86 (dd, $1 \mathrm{H}, \mathrm{CH}_{2},{ }^{3} \mathrm{~J}=7.3,{ }^{2} \mathrm{~J}=13.9$ ); 4.06 (dd, $1 \mathrm{H}, \mathrm{CH}_{2},{ }^{3} \mathrm{~J}=3.6,{ }^{2} \mathrm{~J}=13.9$ ); 4.74 (br.s. $1 \mathrm{H}, \mathrm{OH}) ; 4.96$ (br.s. $1 \mathrm{H}, \mathrm{OH}) ; 6.85$ (s, $1 \mathrm{H}, \mathrm{im}$ ) $; 7.09$ (s, $1 \mathrm{H}, \mathrm{im}) ;$.7.53 (s, $1 \mathrm{H}$, im.). ${ }^{13} \mathrm{C}$ (DMSO-d6, $\delta$, ppm, J/Hz): 49.27, 62.42, 70.09, 120.19, 125.69, 136.97. IR (thin-film, v/sm'): 2979-3409, 1273, 929, 659.

\section{1-[(2-Methyl-2-phenyl-1,3-dioxolan-4-yl)methyl]-1,2,4-triazole (8)}

A mixture of $1.50 \mathrm{~g}(10.5 \mathrm{mmol})$ of 3-(1,2,4-triazol-1-yl)propane-1,2-diol, $1.26 \mathrm{~g}$ (10.5 mmol) of acetophenone, $2.19 \mathrm{~g}(11.6 \mathrm{mmol})$ of monohydrate of $p$-toluol sulfonic acid was boiled in a mixture of 0.04 $\mathrm{L}$ of benzene and $0.02 \mathrm{~L}$ of $n$-buthanol until the separation of water in the Dean-Stark trap $(\sim 7 \mathrm{~h}, \sim 0.4 \mathrm{ml})$ was stopped. The reaction mixture was cooled to $20^{\circ} \mathrm{C}$ and washed with a $10 \%$ solution of sodium hydroxide $(2 \times 0.05 \mathrm{~L})$, water $(2 \times 0.05 \mathrm{~L})$, dried with anhydrous $\mathrm{MgSO}_{4}$, solvents were boiled down, and the oily residue was vacuumed in the oil pump vacuum when heated. The semi-crystalline mass was repeatedly ground with hexane $(7 \times 0.01 \mathrm{~L}) ; 0.47 \mathrm{~g}(18 \%)$ of the product were obtained as white crystals with a boiling point of $85-$ $86{ }^{0} \mathrm{C} . \mathrm{NMR}{ }^{1} \mathrm{H}\left(\mathrm{CDCl}_{3}, \delta, \mathrm{ppm}, \mathrm{J} / \mathrm{Hz}\right): 1.62\left(\mathrm{~s}, 3 \mathrm{H}, \mathrm{CH}_{3}\right) ; 3.67-4.05\left(\mathrm{~m}, 2 \mathrm{H}, \mathrm{CH}_{2}\right) ; 4.21-4.42(\mathrm{~m}, 2.5 \mathrm{H}$, $\left.\mathrm{CH}_{2}, \mathrm{CH}\right) ; 4.61$ (q, 5H, CHO, $\left.{ }^{3} \mathrm{~J}=5.6\right) ; 7.37$ (d, 2H, Ar, $\left.{ }^{3} \mathrm{~J}=8.5\right) ; 7.19-7.54(\mathrm{~m}, 5 \mathrm{H}) ; 7.97$ (s, 1H, tr.); 8.26 (s, $1 \mathrm{H}, \mathrm{tr}$.$) .$

\section{RESULTS AND DISCUSSION}

To study the biological activity, 3-(azol-1-yl)propane-1,2-diols under study were synthesized by several methods (Scheme-1). According to the first method, 3-(1,2,4-triazol-1-yl)propane-1,2-diol and 3-(imidazol1-yl)propane-1,2-diol with quantitative yields were synthesized by hydrolysis of corresponding 4-(azol-1ylmethyl)-2,2-dimethyl-1,3-dioxolanes by boiling in $\mathrm{MeOH}$ in the presence of an equimolar amount of hydrochloric acid.

According to the second method, the target diols were synthesized by oxidation of allylazoles according to Wagner reaction (Scheme-2). Intermediate $\mathrm{N}$-allyl-1,2,4-triazole was obtained with a 53\% yield by alkylation of the sodium salt of 1,2,4-triazole ${ }^{15}$ with a 1,5-fold excess of 3-bromoprop-1-ene in absolute ethanol at $0{ }^{\circ} \mathrm{C}$. Among the alkylation products, 1,4-diallyl-1,2,4-triazolium bromide and 1,3-bis-(1,2,4triazolyl)propane were found using chromatography-mass spectrometry. To reduce the proportion of alkylation by-products, $\mathrm{N}$-allylimidazole was obtained by alkylating a five-fold excess of imidazole with allyl bromide in methanol in the presence of sodium bicarbonate at room temperature for 5 days, with a 
RASĀYAN J. Chem.

Vol. 14 | No. 3 |1711-1716| July - September | 2021

yield of $93 \%$. Intermediate $\mathrm{N}$-allylazoles were oxidized by potassium permanganate with a yield of $65 \%$ and $73 \%$ at $0-5{ }^{\circ} \mathrm{C}$.

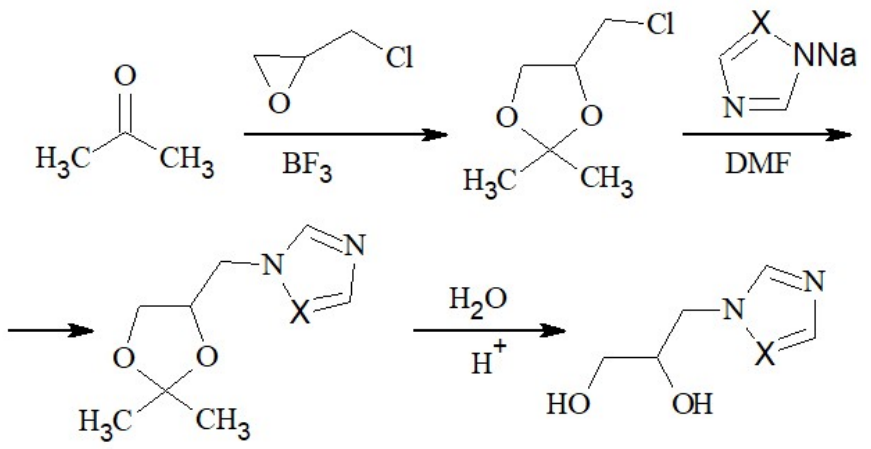

Scheme-1: Synthesis of 3-(azol-1-yl)propane-1,2-diols by hydrolysis of 2,2-dimethyl-4-(azol-1-ylmethyl)-1,3dioxolanes, $(\mathrm{X}=\mathrm{CH}, \mathrm{N})$

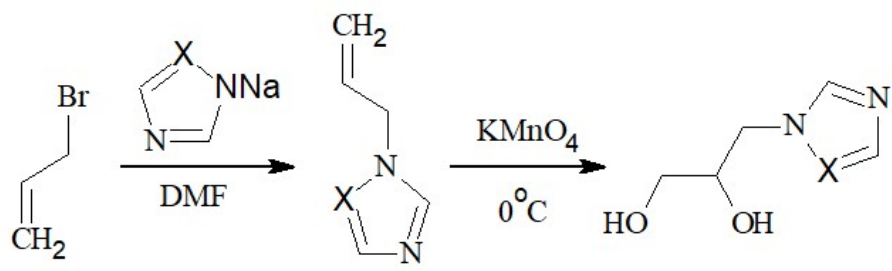

Scheme-2: Synthesis of 3-(azol-1-yl)propane-1,2-diols by Wagner reaction, $(\mathrm{X}=\mathrm{CH}, \mathrm{N})$

According to the third method, 3-(azol-1-yl)propane-1,2-diols were synthesized with a yield of $65-86 \%$ by condensation of imidazole or 1,2,4-triazole with an equimolar amount of glycidol in acetonitrile (Scheme$3)$.

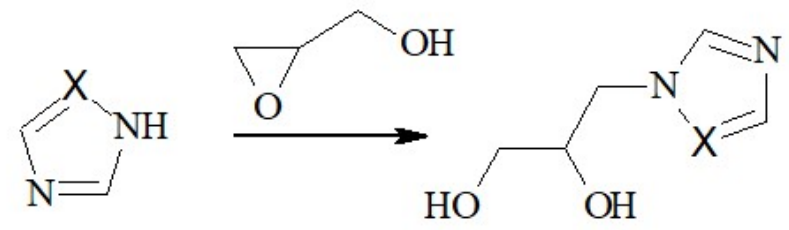

Scheme-3: Synthesis of 3-(azol-1-yl)propane-1,2-diols by condensation of azoles with glycidol, $(\mathrm{X}=\mathrm{CH}, \mathrm{N})$

Synthesized 3-(azol-1-yl)propane-1,2-diols were used in the synthesis of 4-(azol-1-ylmethyl)-1,3dioxolanes, which showed a wide range of biological activities. Method of condensation of 3-(azol-1yl)propane-1,2-diols with ketones in benzene with azeotropic water distillation during catalysis with $p$-toluene sulfonic acid (5 mol \%), equimolar (100 mol \%) and equimolar plus catalytic amounts (105 mol $\%)$ and a five-fold excess $(500 \mathrm{~mol} \%)$ of the catalyst did not lead to the production of target 4-(azol-1ylmethyl)-1,3-dioxolanes even in trace amounts. Nor did the replacement of benzene with toluene or $p$ xylene with a higher boiling point improve the situation. The use of sulfuric acid as a catalyst in the same ratios and with the same solvents also did not lead to the production of 4-azolylmethyl-1,3-dioxolanes.

The experiments on cyclization of diols with ketones in the presence of $3 \AA$ molecular sieves both in absolutized polar solvents (ethanol, DMSO, TGF, acetic acid) and by boiling in benzene, toluene, $p$-xylene; at catalysis with boron trifluoride etherate, anhydrous zinc chloride, copper and magnesium sulfates did not lead to obtaining the target derivatives. Experiments on the fusion of diols with ketones under vacuum in the presence of $\mathrm{TsOH}$, sulfuric acid, ammonium chloride, and phosphorus oxide, as well as without a catalyst, did not give positive results. Experiments on cyclization of benzophenone with imidazolyl methyl oxirane were also unsuccessful, both when catalyzed with boron trifluoride etherate in carbon tetrachloride and with tin tetrachloride in tetrahydrofuran. 
RASĀYAN J. Chem.

Vol. 14 | No. 3 |1711-1716| July - September | 2021

Modification of ketones (benzophenone and acetophenone) to more reactive dimethyl ketals also prevented the production of target dioxolanes. Preliminary modification of hydroxy groups 3-(azol-1-yl)propane1,2-diols by trimethylsilyl groups with both trimethylsilyl chloride and hexamethyldisilazane, both in situ and with preliminary isolation of silylated diol, also did not lead to the production of target diols.

A relatively successful method for the synthesis of 4-(azol-1-ylmethyl)-1,3-dioxolanes happened to be a technique similar to the method of cyclization of phenacylazoles with glycols ${ }^{16}$. The authors performed the interaction at the catalysis of $p$-toluene sulfonic acid (106 mol \%) in the benzene:butanol mixture $(2: 1)$. We used this technique for cyclization of azolylpropanediols with benzophenone and acetophenone (Scheme4). Even though during 7 hours of boiling, the estimated amount of azeotropic water was isolated, which was not separated during further boiling, the conversion of the initial compounds was far from complete, and the yields of the target dioxolanes ranged from $17 \%$ to $24 \%$. At the same time, the isolation of products was much more difficult than originally assumed: azolyl propanediol, which did not enter into the interaction, and a large number of catalysts were removed by washing with aqueous alkali, and ketones by multiple routine extraction (grinding) of a semi-crystalline mass of the product with hexane.

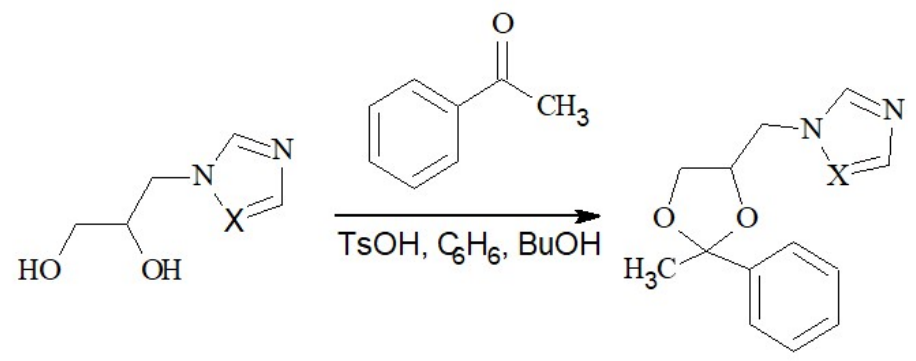

Scheme-4: Synthesis of 4-(azol-1-ylmethyl)-1,3-dioxolanes by condensation of ketones with 3-(azol-1-yl)propane1,2-diols, $(\mathrm{X}=\mathrm{CH}, \mathrm{N})$

\section{CONCLUSION}

Taking into account the total yield and the number of stages, the optimal method for obtaining 3-(1Himidazol-1-yl)propane-1,2-diol is the interaction of imidazole with glycidol since the product is obtained in one stage and with the highest total yield, $65 \%$. However, it should be noted that during hydrolysis of 2,2-dimethyl-4-(azol-1-ylmethyl)-1,3-dioxolanes, the target diols were obtained with spectral purity, without additional isolation methods.

The optimal technique for the synthesis of substituted 4-(azol-1-ylmethyl)-1,3-dioxolanes in terms of yields and labor costs, as well as industrial applicability, is the alkylation of sodium salts of 1,2,4-triazole or imidazole with 4-chloromethyl-1,3-dioxolanes obtained by condensation of ketones with 3-chloro-1,2propanediol.

3-(azol-1-yl)propane-1,2-diols were tested for biological activity.

The studied compounds showed low fungicidal and growth-regulating activity, which confirms that the entire molecule, including the lipophilic fragment of the initial ketone, is responsible for the manifestation of high fungicidal activity of 2,2-disubstituted 4-(azol-1-ylmethyl)-1,3-dioxolanes. ${ }^{17-19}$

Further investigation of methods of condensation of 3-(azol-1-yl)propane-1,2-diols with ketones will significantly reduce labor costs when searching for new biologically active substances in the range of 4(azol-1-yl)-1,3-dioxolanes.

\section{REFERENCES}

1. V.S. Talismanov, S.V. Popkov, S.S. Zykova, O.G. Karmanova and G.V. Tsaplin, Journal of Pharmaceutical Sciences and Research, 10(8), 2041(2018)

2. V.S. Talisnanov, S.V. Popkov, S.S. Zykova and O.G. Karmanova, Journal of Pharmaceutical Sciences and Research, 10(5), 1267(2018)

3. V.S. Talismanov and S.V. Popkov, Russian Chemical Bulletin, 56, 975(2007), https://doi.org/10.1007/s11172-007-0147-4

4. V.S. Talismanov, S.V. Popkov, O.G. Karmanova and S.S. Zykova, International Journal of Pharmaceutical Research, 11(2), 315(2019), https://doi.org/10.31838/ijpr/2019.11.02.051 
RASĀYAN J. Chem.

Vol. 14 | No. 3 |1711-1716| July - September | 2021

5. V.S. Talismanov, S.V. Popkov, S.S. Zykova and O.G. Karmanova, Journal of Pharmaceutical Sciences and Research, 10(7),1780(2018)

6. V.S. Talismanov, S.V. Popkov, S.S. Zykova, O.G. Karmanova and G.V. Tsaplin, Journal of Pharmaceutical Sciences and Research, 10(6), 1625(2018)

7. V.S. Talismanov, S.V. Popkov, S.S. Zykova and O.G. Karmanova, Journal of Pharmaceutical Sciences and Research, 10(2), 328(2018)

8. V.S. Talismanov, S.V. Popkov, S.S. Zykova and O.G. Karmanova, Journal of Pharmaceutical Sciences and Research, 10(4), 950(2018)

9. V.S. Talismanov, S.V. Popkov, S.S. Zykova, O.G. Karmanova and S.A. Bondarenko, Journal of Pharmaceutical Sciences and Research, 10(1), 152(2018)

10. D. Praveena, E. Laxminarayana and M. Ramesh, Rasayan Journal of Chemistry, 12(3), 1646(2019) https://doi.org/10.31788/RJC.2019.1235335

11. K. Sujatha, B. Kalluraya and S.D. Joshi, Rasayan Journal of Chemistry, 12(3), 1405(2019), https://doi.org/10.31788/RJC.2019.1235200

12. P. Kate, S. Gaikwad, T. Lokhande, A. Shaikh, B. Sonawane, P. Choudhari and M. Bachute, Rasayan Journal of Chemistry, 11(4), 1441(2018), https://doi.org/10.31788/RJC.2018.1143080

13. G. Sharma, S. Anthal, A. Jayashree, B. Narayana, B.K. Sarojini and R. Kant, Rasayan Journal of Chemistry, 12(2), 773(2019), https://doi.org/10.31788/RJC.2019.1225157

14. K. Ramalingam, D. Ramesh and B. Sreenivasulu, Rasayan Journal of Chemistry, 12(2), 583(2019), https://doi.org/10.31788/RJC.2019.1225096

15. D.A. Karachev and S.V. Popkov, Chemistry of Heterocyclic Compounds, 41, 987(2005), https://doi.org/10.1007/s10593-005-0265-6

16. F. Macaev, Chemistry Journal of Moldova, 1, 43(2006), https://doi.org/10.19261/cjm.2006.01(1).10

17. S.S. Zykova, G.V. Tsaplin, V.S. Talismanov, I.P. Bulatov, S.V. Popkov and O. Karmanova International Journal of Pharmaceutical Research, 13(1), 309(2021), https://doi.org/10.31838/ijpr/2021.13.01.056

18. N. Tokareva, S. Zykova and V. Talismanov, E3S Web of Conferences, 217, 08006(2020), https://doi.org/10.1051/e3sconf/202021708006

19. V.S. Talismanov, S.V. Popkov, A.L. Alekseenko, S.S. Zykova and O.G. Karmanova, International Journal of Pharmaceutical Research, 11(3), 1237(2019), https://doi.org/10.31838/ijpr/2019.11.03.096

[RJC-6537/2021] 